\title{
KEBIJAKAN HUKUM PIDANA DALAM PERTANGGUNGJAWABAN KORPORASI DI BIDANG KETENAGAKERJAAN (Undang-Undang Nomor 13 Tahun 2003 Tentang Ketenagakerjaan)
}

\author{
Eric Prima Setiawan \\ Alumni Magister Ilmu Hukum \\ Universitas Borneo Tarakan \\ Tarakan, Indonesia \\ ericksky888@gmail.com
}

\begin{abstract}
The development process of modernization shows that corporations play an important role in society. However, in achieving the goals and interests, corporations occasionally commit acts in violation of the law and result in the victim suffering a loss. Corporations in the field of labor also commit offenses or crimes in the form of actions that ignore the security and safety of laborers. It means that the corporation has ignored the interest of the laborers. Act No. 13 of 2003 on Labor is the legal basis for the laborers. Therefore it is necessary to make unequi vocal and explicit arrangements about corporations' liability in general within the act. The method used in this thesis is a normative juridical with a conceptual and legislation approach. Act No. 13 of 2003 on Labor still has not regulate explicitly the corporations' liability to the victims of corporations' crime. It is because there is no specific regulation on sanctions replacement if the corporation does not pay the principal financial penalties imposed and there is no provision governing when a corporation does not meet its obligations to pay for the rights and/or compensation to laborers. The effort of ius constituendum related to corporations' liability is to en act a separate regulation expressly and explicitly regarding corporations' liability in general within the act. Thus, the criminal law policy of corporations' liability in the field of labor can be realized.
\end{abstract}

Keywords : Corporate, Corporations' Liability, Labor.

\section{PENDAHULUAN}

Manusia alamiah (natuurlijk persoon) dan korporasi merupakan subyek tindak pidana. Namun demikian antara manusia alamiah dan korporasi sebagai subyek tindak pidana mempunyai perbedaan. Perbedaan antara sifat manusia alamiah dengan sifat korporasi sebagai subyek tindak pidana mengakibatkan tidak semua kejahatan dapat dilakukan korporasi. 
Bentuk-bentuk kejahatan yang dapat dilakukan korporasi sesuai dengan sifat korporasi sebagai subyek tindak pidana.

Korporasi merupakan perkumpulan orang-orang yang melakukan tindakan bersama-sama di dalam suatu badan yang diciptakan oleh hukum serta dijalankan menurut ketentuan hukum yang berlaku untuk menjalankan aktivitas atau kegiatan yang sah baik itu sebagai bagian dari fungsi pemerintahan maupun dalam kegiatan di bidang bisnis kemudian berakhirnya suatu badan tersebut pun ditentukan oleh adanya undangundang yang mengaturnya.

Korporasi banyak memberikan kontribusi perkembangan suatu negara, terutama dalam bidang ekonomi, misalnya pemasukan negara dalam bentuk pajak maupun devisa, sehingga dampak korporasi tampak sangat positif. Namun di sisi lain, korporasi juga tak jarang menciptakan dampak negatif, seperti pencemaran, pengurasan sumber daya alam, persaingan secara curang, manipulasi pajak, eksploitasi terhadap buruh, menghasilkan produk-produk yang membahayakan pemakainya, serta penipuan terhadap konsumen. ${ }^{1}$ Adanya kecenderungan korporasi melakukan kejahatan dalam mencapai tujuannya, maka dalam hukum pidana kini telah terjadi pergeseran pandangan bahwa korporasi juga merupakan subyek hukum pidana di samping manusia alamiah.

Korporasi dalam hal kaitannya dengan bidang ketenagakerjaan bahwa dalam rangka pembangunan nasional untuk pembangunan manusia Indonesia yang seutuhnya dan pembangunan masyarakat Indonesia seluruhnya untuk mewujudkan masyarakat yang sejahtera, adil, makmur, yang merata, baik materiil maupun spritual berdasarkan Pancasila dan Undang-Undang Dasar Negara Republik Indonesia Tahun 1945 (UUD 1945) yang menyatakan bahwa dalam pelaksanaan pembangunan nasional peranan tenaga kerja dalam suatu korporasi mempunyai peranan yang sangat penting

\footnotetext{
1 Setiyono, Kejahatan Korporasi: Analisis Viktimologis dan Pertanggungjawaban Korporasi dalam Hukum Pidana Indonesia, Bayumedia Publishing, Malang, 2005, h. 17.
} 
sebagai pelaku dan tujuan pembangunan. Sehingga mempunyai peranan yang sangat signifikan dalam aktivitas perekonomian nasional, yaitu meningkatkan produktivitas dan kesejahteraan masyarakat.

Kejahatan yang dilakukan oleh korporasi lebih berbahaya di banding kejahatan yang dilakukan oleh seseorang, karena melibatkan masyarakat luas, pemerintah maupun individu. Isu-isu kejahatan korporasi di bidang ketenagakerjaan diantaranya seperti Pemutusan Hubungan Kerja (PHK) secara sepihak yang dilakukan oleh perusahaan. Disamping itu, ada mengenai tenaga kerja yang sampai meninggal dan diperkosa bahkan dibunuh oleh majikannya dalam menuntut haknya, sering terjadinya kecelakaan kerja dan penyakit karena perhatian akan pengetahuan dan kesadaran yang kurang dari pengusaha tentang syarat Kesehatan dan Keselamatan Kerja (K3) terhadap pekerja/buruhnya. Tenaga kerja/buruh diperlakukan secara senonoh karena dianggap sebagai budak yang dapat diperlakukan semaunya oleh pengusaha.

Berdasarkan bentuk kejahatan korporasi di bidang ketenagakerjaan tersebut diatas, dapat digambarkan bahwa pelanggaran yang dilakukan korporasi bidang ketenagakerjaan tidak hanya mengabaikan hak normatif dan kesejahteraan pekerja/buruhnya namun juga tidak menjamin keamanan dan K3. Kejahatan korporasi terhadap buruh atau tenaga kerja adalah yang berupa perbuatan-perbuatan yang mengabaikan keamanan dan keselamatan kerja buruh, karena itu berarti mengabaikan apa yang menjadi kepentingan dari para buruh yang bersangkutan. Sehubungan dengan kejadian tersebut, perlu adanya penerapan pertanggungjawaban secara pidana terhadap korporasi dalam UU Ketenagakerjaan.

UU Ketenagakerjaan merupakan perundang-undangan administrasi yang bersanksi pidana memuat ketentuan pidana sebagaimana diatur dalam bab XVI yaitu Pasal 183 sampai dengan Pasal 189 dan memuat ketentuan sanksi administratif yaitu Pasal 190. Diperlukan secara tegas dan eksplisit mengenai ketentuan dalam hal pertanggungjawaban korporasi secara umum 
dalam UU Ketenagakerjaan sebagai wujud jaminan perlindungan hukum dan kepastian hukum terhadap masyarakat terkhusus kepada tenaga kerja/buruh.

Adanya perlindungan hukum juga tidak terlepas pada peranan penegak hukum, yang berfungsi sebagai alat dalam menegakkan hukum untuk mencapai ketertiban dan keadilan pada proses peradilan dan untuk melindungi korban individual maupun kelompok akibat tindak pidana korporasi. Hukum pidana harus responsif untuk menanggulangi berbagai kejahatan yang dilakukan oleh korporasi dengan menempatkan korporasi sebagai subyek hukum dalam hukum pidana yang dapat dipertanggungjawabkan sehingga memberikan efek jera (deterent effect).

Kebijakan dalam penerapan pertanggungjawaban terhadap korporasi dalam UU Ketenagakerjaan yaitu dalam rangka untuk memberikan jaminan perlindungan hukum, kepastian hukum dan keadilan khususnya terhadap tenaga kerja serta mencapai tujuannya yaitu mensejahterakan masyarakat. Korban tindak pidana korporasi khususnya di bidang ketenagakerjaan membutuhkan pemulihan kembali berupa kompensasi maupun hukuman kepada pelaku tindak pidana sebagai suatu bentuk pertanggungjawaban dari pelaku yang melakukan tindak pidana.

\section{RUMUSAN MASALAH}

Untuk itu penulis akan membahas mengenai :

1. Bentuk pertanggungjawaban korporasi di bidang ketenagakerjaan.

2. Ius constituendum pertanggungjawaban korporasi di bidang ketenagakerjaan.

\section{METODE PENELITIAN}

Jenis penelitian ini yaitu yuridis normatif. Penelitian ini melakukan analisis terhadap asas-asas hukum dengan mengacu pada norma-norma hukum. Metode pendekatan yang digunakan dalam penelitian ini adalah pendekatan perundang-undangan (statute approach) dan pendekatan konsep (conseptual approach). Jenis sumber bahan hukum yang digunakan adalah 
bahan hukum primer yaitu UU Ketenagakerjaan, bahan hukum sekunder yaitu bahan penelitian kepustakaan dan media internet. Prosedur pengumpulan bahan hukum dilakukan dengan cara studi dokumen, studi kepustakaan, dan studi internet. Prosedur analisis bahan hukum dilakukan dengan menggunakan metode content analisis (analisis isi). Content analysis digunakan untuk mendeskripsikan dan menginterpretasikan isi peraturan dalam UU Ketenagakerjaan yang berkaitan dengan pertanggungjawaban pidana bagi korporasi. Proses analisa data dilakukan dengan cara interpretasi yakni proses analisa menurut bahasa/gramatikal dan interpretasi sistematis.

\section{PEMBAHASAN}

\section{Bentuk Pertanggungjawaban Korporasi di Bidang Ketenagakerjaan}

Perkembangan penegakkan hukum pidana berdasarkan hukum administrasi tersebut, di Indonesia hampir semua perundangan administrasi yang bersanksi pidana telah mencantumkan korporasi sebagai subyek hukum pidana. $^{2}$ Melihat pada UU Ketenagakerjaan bahwasannya dapat diidentifikasikan sebagai perundangundangan administrasi yang bersanksi pidana, baik yang secara tegas menyebutkan bahwa korporasi sebagai subyek hukum pidana, maupun yang hanya menyebutkan dengan istilah lain, namun pada intinya maksudnya adalah sama, ataupun tidak menyebutkan sama sekali korporasi sebagai subyek hukum pidana dalam undangundang ini. $^{3}$

Apabila mencermati keberlakuan UU Ketenagakerjaan pada hakikatnya selain menentukan perbuatan-perbuatan tindak pidana yang dilakukan merupakan perbuatan manusia alamiah, namun yang demikian pula dapat dimaksudkan sebagai perbuatan tindak pidana yang dilakukan oleh korporasi, sebagaimana di dalam Pasal 1 angka 4 memuat pengertian bahwa : "Pemberi kerja adalah orang perseorangan, pengusaha, badan

2 M. Arief Amrullah, Kejahatan Korporasi: The Hunt for Mega-Profits and The Attack on Democracy, Bayumedia Publishing, Malang, 2006, h. 227. ${ }^{3}$ Ibid., h.228. 
hukum, atau badan-badan lainnya yang mempekerjakan tenaga kerja dengan membayar upah atau imbalan dalam bentuk lain”. Kemudian Pasal 1 angka 5 : menyatakan, "Pengusaha" adalah :

a. orang perseorangan, persekutuan, atau badan hukum yang menjalankan suatu perusahaan milik sendiri;

b. orang perorangan, persekutuan, atau badan hukum yang secara berdiri sendiri menjalankan perusahaan bukan miliknya;

c. orang perorangan, persekutuan, atau badan hukum yang berada di Indonesia mewakili perusahaan sebagaimana dimaksud dalam huruf a dan b yang berkedudukan diluar wilayah Indonesia.

Lebih lanjut di dalam Pasal 1 angka 6 : menyatakan, "Perusahaan" adalah :

a. setiap bentuk usaha yang berbadan hukum atau tidak, milik orang perseorangan, milik persekutuan, atau milik badan hukum, baik milik swasta maupun milik negara yang mempekerjakan pekerja / buruh dengan membayar upah atau imbalan dalam bentuk lain;

b. usaha-usaha sosial dan usaha-usaha lain yang mempunyai pengurus dan mempekerjakan orang lain dengan membayar upah atau imbalan dalam bentuk lain.

Penggunaan istilah lain selain korporasi, yaitu "pengusaha dan perusahaan" (Pasal 1 angka 5 dan 6) dalam UU Ketenagakerjaan ini dapat dinyatakan sebagai pelaku tindak pidana atau subyek tindak pidana, dan kepadanya dapat dibebankan suatu pertanggungjawaban pidana atas perbuatan kejahatan dan atau pelanggaran hukum yang dilakukannya.

Pada hakikatnya UU Ketenagakerjaan ini merupakan perundangundangan administrasi yang bersanksi pidana. Di dalam pengaturan undangundang ini terdapat ketentuan mengenai tindak pidana korporasi, tetapi tidak terdapat mengatur secara eksplisit atau secara tersendiri mengenai tindak pidana korporasi tersebut. ${ }^{3}$

Korporasi dalam UU Ketenagakerjaan ini dalam hal kaitannya mengenai bentuk pertanggungjawaban korporasi terhadap korban dari kejahatan dan atau pelanggaran yang dilakukan korporasi ialah tidak terlepaskannya kewajiban korporasi untuk harus memenuhi sanksi yaitu membayar ganti kerugian kepada tenaga kerja atau pekerja/buruh, sebagaimana diatur didalam Ketentuan Pidana dalam Pasal 189, yaitu :

${ }^{3}$ Hasbullah F. Sjawie, Direksi Perseroan Terbatas serta Pertanggungjawaban Pidana Korporasi, Citra Aditya Bakti, Bandung, 2013, h. 329. 
"Sanksi pidana penjara, kurungan, dan/atau denda tidak menghilangkan kewajiban pengusaha membayar hak-hak dan/atau ganti kerugian kepada tenaga kerja atau pekerja/buruh". Terhadap bentuk pertanggungjawabannya adalah kepada korban yaitu tidak menghilangkan kewajiban pengusaha membayar hak-hak dan/atau ganti kerugian kepada tenaga kerja atau pekerja/buruh. Dengan kata lain, hal ini merupakan suatu bentuk pertanggungjawaban korporasi secara langsung/nyata terhadap korban kejahatan korporasi. Namun apakah aturan atau ketentuan pasal ini sudah cukup tegas untuk memberikan jaminan bentuk pertanggungjawaban korporasi terhadap korban atau tidak.

UU Ketenagakerjaan ini tidak ada ketentuan yang mengatur secara tegas lebih lanjut mengenai sanksi pengganti apabila pelaku atau subyek tindak pidana dalam hal ini adalah korporasi tidak melaksanakan kewajibannya berupa pemenuhan hak-hak dan/atau pembayaran ganti kerugian terhadap korban kejahatan korporasi (tidak memenuhi kewajiban Pasal 189 undang-undang ini) dan/atau sanksi denda yang seharusnya dibayarkan kepada negara dibidang ketenagakerjaan (tidak memenuhi kewajiban dalam pasal-pasal Ketentuan Pidana undang-undang ini). Hal ini tentu saja merupakan celah bagi korporasi untuk tidak membayar ganti kerugian kepada korban dan atau denda yang seharusnya dibayarkan kepada negara menurut ketentuan yang diatur di dalam ketentuan pidana UU Ketenagakerjaan.

Konsekuensi yuridis dengan tidak adanya pengaturan khusus mengenai sanksi pengganti denda yaitu terjadi kekosongan hukum didalam UU

Ketenagakerjaan. Kekosongan hukum tersebut terkait dengan apabila korporasi tidak dapat memenuhi kewajibannya membayar denda sesuai sanksi yang dibebankan. Dampak dari adanya kekosongan hukum tersebut adalah tidak adanya ketentuan atau aturan yang dapat memaksa korporasi 
yang tidak melaksanakan kewajibannya dalam hal pembayaran ganti kerugian atau denda tersebut. ${ }^{4}$

\section{Ius Constituendum Pertanggungjawaban Korporasi di Bidang Ketenagakerjaan}

Keadaan yang menunjukkan semakin besarnya peranan korporasi dalam berbagai bidang dan adanya kecenderungan korporasi melakukan kejahatan dalam mencapai tujuannya, maka telah terjadi pergeseran pandangan bahwa korporasi sebagai subyek hukum pidana di samping manusia alamiah (natuurlijk persoon). Maka dengan demikian penolakan pemidanaan korporasi berdasarkan doktrin universitas delinquere non potest telah mengalami perubahan dengan menerima konsep pelaku fungsional. ${ }^{5}$

Menindaklanjuti kembali pada UU Ketenagakerjaan, bahwasannya undangundang ini tidak mengatur ketentuan secara eksplisit mengenai kedudukan korporasi secara umum yakni terkait belum ada pengaturan secara eksplisit dan secara langsung yang memuat ketentuan yang menyatakan secara tegas bahwa korporasi merupakan subyek tindak pidana yang dapat dibebebankan tuntutan pertanggungjawaban secara pidana kepada korporasi dan/atau pengurusnya. Selain itu juga di dalam UU Ketenagakerjaan ini sebenarnya ada ketentuan mengenai tindak pidana yang dilakukan oleh korporasi, namun tidak terdapat pengaturan tersendiri, tidak mengatur secara tersendiri mengenai tindak pidana korporasi. ${ }^{6}$

UU Ketenagakerjaan telah memuat pengaturan ketentuan pidana, namun dirasa masih kurang dan tidak eksplisit, terutama mengenai pertanggungjawaban korporasi terhadap korban. Pengaturan lebih lanjut dalam hal pertanggungjawaban pidana korporasi tentu saja tidak cukup hanya dengan menyebutkan korporasi sebagai subyek tindak pidana saja, melainkan juga harus menentukan aturan mengenai sistem pidana dan

\footnotetext{
4 Evan Elroy Situorang, Tesis Kebijakan Formulasi Pertanggungjawaban Pidana Korporasi Terhadap Korban Kejahatan Korporasi (online), http://eprints.undip.ac.id/16888/1/EVAN ELROY SITUORANG.pdf (15 November 2012), h. 187.

${ }^{5}$ Setiyono, Op.Cit., h. 122.

${ }^{6}$ Hasbullah F. Sjawie, Op.Cit., h. 329.
} 
pemidanaannya. Berdasarkan hal tersebut, sebagai wujud ius constituendum, sangat dirasa perlu menempatkan pengaturan lebih lanjut mengenai pertanggungjawaban korporasi dalam undang-undang ini.

Berdasarkan hal tersebut diatas, maka dilakukan reformulasi pertanggungjawaban pidana terhadap korban kejahatan korporasi di bidang ketenagakerjaan antara lain meliputi ketentuan mengenai :

(a) Kapan suatu tindak pidana dapat dikatakan sebagai tindak pidana yang dilakukan oleh korporasi

Pada UU Ketenagakerjaan perlu terlebih dahulu mencantumkan ketentuan pengertian korporasi, dengan mengadopsi pengertian korporasi menurut UU Tipikor dalam Pasal 7 aya (1), sehingga berbunyi : "Korporasi adalah kumpulan orang dan/atau kekayaan yang terorganisasi baik merupakan badan hukum maupun bukan badan hukum"

Ketentuan yang mensyaratkan mengenai kapan suatu korporasi dikatakan melakukan tindak pidana, melihat contoh pada UU Tipikor dalam Pasal 20 ayat (2)-nya sebagaimana berbunyi :

Tindak pidana korupsi dilakukan oleh korporasi apabila tindak pidana tersebut dilakukan oleh orang-orang baik berdasarkan hubungan kerja maupun berdasarkan hubungan lain, bertindak dalam lingkungan korporasi tersebut baik sendiri maupun bersama-sama.

Berdasarkan bunyi pasal tersebut diatas, dikatakan bahwa suatu korporasi hanya dapat dibebani pertanggungjawaban pidana sepanjang tindak pidana tersebut dilakukan oleh "orang-orang yang memiliki hubungan dengan korporasi, baik hubungan yang berdasarkan kepada hubungan kerja maupun yang berdasarkan hubungan lain selain hubungan kerja". ${ }^{7}$

Beranjak dari ketentuan diatas, maka perumusan pengaturan mengenai ketentuan yang mensyaratkan kapan suatu korporasi dapat

${ }^{7}$ Sutan Remy Sjahdeini, Pertanggungjawaban Pidana Korporasi, Grafiti Pers, Jakarta, 2007, h. 153. 
dikatakan sebagai perbuatan melakukan tindak pidana, sekiranya dapat berbunyi :

(1) "Tindak pidana ketenagakerjaan dilakukan oleh korporasi apabila tindak pidana tersebut dilakukan oleh orang-orang baik berdasarkan hubungan kerja atau berdasarkan hubungan lain yang bertindak dalam lingkup usaha korporasi baik sendiri atau bersama-sama".

(2) "Pertanggungjawaban pidana terhadap pengurus korporasi dibatasi sepanjang pengurus memiliki kedudukan fungsional dalam struktur organisasi korporasi".

(3) "Korporasi dapat dipertanggungjawabkan secara pidana terhadap suatu perbuatan yang dilakukan untuk dan/atau atas nama korporasi, jika perbuatan tersebut termasuk dalam lingkup usahanya sebagaimana ditentukan dalam anggaran dasar atau ketentuan lain yang berlaku bagi korporasi yang bersangkutan".

(b) Siapa yang dapat dituntut pertanggungjawaban dan dijatuhi pidana atas kejahatan yang dilakukan oleh korporasi

Berkenaan dengan penentuan siapa yang dapat dipertanggungjawabkan terhadap tindak pidana yang dilakukan oleh korporasi merupakan suatu hal yang sangat penting, karena sangat erat kaitannya dengan mempertanggungjawabkan pidananya atas tindak pidana atau kejahatan yang dilakukan oleh korporasi.

Apabila melihat pada UU Tipikor yang memuat ketentuan mengenai korporasi sebagai subyek tindak pidana, sebagaimana diatur dalam ketentuan Pasal 20 ayat (1), yang berbunyi : "Dalam hal tindak pidana korupsi dilakukan oleh atau atas nama suatu korporasi, maka tuntutan dan penjatuhan pidana dapat dilakukan terhadap korporasi dan/atau pengurusnya".

Berdasarkan ketentuan Pasal 20 ayat (1) tersebut diatas, maka dalam hal ini UU Ketenagakerjaan mengadopsi pengaturan yang sama halnya dengan ketentuan UU Tipikor. Penentuan korporasi sebagai subyek tindak pidana serta dapat dibebankan pertanggungjawaban dan dituntut secara pidana, dapat berbunyi sebagai berikut : 
(1) "Apabila suatu tindak pidana dilakukan oleh atau atas nama korporasi, maka tuntutan dan penjatuhan pidana dapat dilakukan terhadap korporasi dan/atau pengurusnya".

(c) Jenis sanksi yang sesuai dengan subyek tindak pidana berupa korporasi yang berorientasi pada pemberian ganti kerugian kepada korban

Pada bagian ini merupakan bagian yang sangat substansial, karena menyangkut langsung pembebanan pertanggungjawaban korporasi. Jenis sanksi pidana yang relevan ditetapkan terhadap korporasi ialah berupa pidana pokok dan pidana tambahan. Berbagai undang-undang pidana Indonesia baru menetapkan denda sebagai sanksi pidana pokok bagi korporasi. Beberapa sanksi yang pada saat ini ditentukan sebagai sanksi pidana tambahan seyogianya dapat diangkat sebagai sanksi pidana pokok bagi korporasi. ${ }^{8}$

UU Ketenagakerjaan merupakan undang-undang yang dapat menuntut korporasi sebagai pelaku tindak pidana, menentukan sanksi pidana penjara dan denda sebagai sanksi alternatif dalam beberapa pasalnya. Korporasi dalam undang-undang ini hanya mungkin dituntut secara pidana karena melanggar pasal-pasal yang memuat sanksi-sanksi pidana alternatif. Apabila kedua sanksi pidana itu bersifat alternatif, maka kepada pengurusnya dapat dijatuhkan sanksi pidana penjara saja atau sanksi pidana denda, atau kedua sanksi tersebut dijatuhkan secara kumulatif. Sementara itu, kepada korporasinya hanya dapat dijatuhkan sanksi pidana denda (secara alternatif hanya berlaku denda). ${ }^{9}$

UU Ketenagakerjaan ini menentukan sanksi pidana denda sebagai sanksi pidana pokok yang dapat dijatuhkan kepada korporasi yang melakukan tindak pidana. Namun, apakah ketentuan penjatuhan pidana denda tersebut telah diikuti oleh aturan mengenai pidana pengganti denda apabila sanksi denda yang telah dijatuhkan kepada korporasi

${ }^{8}$ Sutan Remy Sjahdeini, Op.Cit., h. 205.

${ }^{9}$ Ibid., h. 206. 
tidak dilaksanakan. Berdasarkan kenyataan ini, seyogyianya ditegaskan ketentuan sanksi pidana berupa sanksi pidana tambahan. Selanjutnya dapat diteruskan diterapkan sanksi administratif.

UU Ketenagakerjaan memuat ketentuan sanksi administratif, yaitu Pasal 190 ayat (2) menentukan jenis-jenis sanksi administratif yang dijatuhkan, yaitu berupa : a. teguran;

b. peringatan tertulis;

c. pembatasan kegiatan usaha;

d. pembekuan kegiatan usaha;

e. pembatalan persetujuan;

f. pembatalan pendaftaran;

g. penghentian sementara sebagian atau seluruh alat produksi;

h. pencabutan ijin.

Jika dilihat pada ketentuan ayat (2) tersebut bahwasannya diketahui jenis sanksi yang termasuk ke dalam ranah sanksi administratif dapat disebut pula termasuk ke dalam ranah sanksi pidana tambahan, yaitu sanksi yang berupa penghentian seluruh alat produksi dan sanksi yang berupa pencabutan ijin usaha. Berkaitan dengan ketentuan sanksi administratif dalam UU Ketenagakerjaan ini, maka perlu menambahkan bentuk sanksi pidana pengganti denda apabila sanksi denda tidak dilaksanakan oleh korporasi, di dalam ayat (2)-nya tersebut sebagai aturan pidana pengganti denda (dapat disebut sanksi pidana tambahan) yaitu berupa : a. perampasan barang tertentu;

b. pengumuman keputusan hakim.

Pada akhirnya dapat diketahui, selain ketentuan sanksi administratif yang telah diatur di dalam undang-undang ini, maka selanjutnya dapat memuat ketentuan secara tegas sanksi pidana pengganti denda apabila korporasi tidak memenuhi kewajibannya untuk membayar ganti kerugian kepada korban sebagai akibat kejahatan korporasi yang dilakukannya, yaitu berupa sanksi pidana tambahan. Maka dengan demikian sanksi pidana tambahan sekiranya dapat diatur sebagai berikut :

1. Penghentian seluruh alat produksi (Pasal 190 ayat 2); 
2. Perampasan barang tertentu;

3. Pengumuman keputusan hakim;

4. Pencabutan ijin (Pasal 190 ayat 2).

\section{PENUTUP}

\section{Kesimpulan}

Berdasarkan hasil dan pembahasan, maka dapat ditarik kesimpulan yaitu sebagai berikut :

1. Bentuk pertanggungjawaban korporasi dalam UU Ketenagakerjaan diatur dalam

Pasal 189, yaitu : "Sanksi pidana penjara, kurungan, dan/atau denda tidak menghilangkan kewajiban pengusaha membayar hak-hak dan/atau ganti kerugian kepada tenaga kerja atau pekerja/buruh". Hal ini mencerminkan bentuk pertanggungjawaban korporasi yang secara langsung/nyata terhadap korban kejahatan korporasi. Namun ketentuan pasal ini belum mencerminkan bentuk pertanggungjawaban korporasi terhadap korban terkait tidak ada pengaturan khusus mengenai sanksi pengganti apabila korporasi tidak memenuhi denda. Konsekuensi yuridis tidak adanya sanksi pengganti denda ialah terjadinya kekosongan hukum dalam UU Ketenagakerjaan.

2. Ius constituendum terkait pertanggungjawaban korporasi adalah dengan memberlakukan pengaturan secara eksplisit mengenai pertanggungjawaban korporasi secara umum dalam undang-undang ini, yaitu mencantumkan ketentuan sebagai berikut:

1. Korporasi adalah kumpulan orang dan/atau kekayaan yang terorganisasi baik merupakan badan hukum maupun bukan badan hukum.

2. Apabila suatu tindak pidana dilakukan oleh atau atas nama korporasi, maka tuntutan dan penjatuhan pidana dapat dilakukan terhadap korporasi dan/atau pengurusnya.

3. Tindak pidana ketenagakerjaan dilakukan oleh korporasi apabila tindak pidana tersebut dilakukan oleh orang-orang baik berdasarkan hubungan kerja atau berdasarkan hubungan lain yang bertindak dalam lingkup usaha korporasi baik sendiri atau bersama-sama. 
4. Korporasi dapat dipertanggungjawabkan secara pidana terhadap suatu perbuatan yang dilakukan untuk dan/atau atas nama korporasi, jika perbuatan tersebut termasuk dalam lingkup usahanya sebagaimana ditentukan dalam anggaran dasar atau ketentuan lain yang berlaku bagi korporasi yang bersangkutan.

Kemudian sebagai pidana tambahan, dapat berbunyi sebagai berikut :

Selain pidana denda yang dijatuhkan terhadap korporasi sebagaimana melanggar pasal-pasal yang diatur dalam ketentuan pidana undangundang ini, terhadap korporasi juga dapat dijatuhkan pidana tambahan :

1. Penghentian seluruh alat produksi (Pasal 190 ayat 2);

2. Perampasan barang tertentu;

3. Pengumuman keputusan hakim;

4. Pencabutan ijin (Pasal 190 ayat 2)

Saran

Dari beberapa kesimpulan yang dikemukakan diatas, maka selanjutnya dapat ditarik saran sebagai berikut :

1. Kepada pihak pemerintah khususnya para legislator, untuk segera melakukan reformulasi terhadap UU Ketenagakerjaan ini sebagai upaya lebih lanjut terhadap pengaturan secara eksplisit mengenai pertanggungjawaban korporasi di dalam undang-undang ini, mengingat kebutuhan sebagai bentuk perlindungan hukum masyarakat dan jaminan kepastian hukum tentunya terhadap korban kejahatan korporasi yang dalam hal ini khususnya kepada tenaga kerja/buruh yang bersinggungan langsung dengan keberadaan korporasi itu sendiri, sehingga terpenuhi hak-hak dasar dan jaminan perlindungan yang mendasar bagi tenaga kerja dan pekerja/buruh serta menjamin kepastian hukum.

2. Reformulasi pertanggungjawaban pidana terhadap korban kejahatan korporasi di bidang ketenagakerjaan antara lain meliputi ketentuan mengenai :

1. Kapan suatu tindak pidana dapat dikatakan sebagai tindak pidana yang dilakukan oleh korporasi;

2. Siapa yang dapat dituntut pertanggungjawaban dan dijatuhi pidana atas kejahatan yang dilakukan oleh korporasi; 
3. Jenis sanksi yang sesuai dengan subyek tindak pidana berupa korporasi yang berorientasi pada pemberian ganti kerugian kepada korban.

Merupakan suatu hal yang penting pula untuk membedakan jenis-jenis pidana yang dapat diterapkan kepada orang dan jenis-jenis pidana yang dapat diterapkan kepada korporasi, agar supaya korporasi yang melakukan tindak pidana dapat dijatuhi pidana sesuai dengan kapasitasnya sebagai subyek tindak pidana yang bukan orang (recht person).

\section{DAFTAR BACAAN}

Ali, Mahrus, Asas-Asas Hukum Pidana Korporasi, RajaGrafindo Persada, Jakarta, 2013.

Amiruddin dan Zainal Asikin, Pengantar Metode Penelitian Hukum, PT. Raja Grafindo Persada, Jakarta, 2003.

Amrullah, M. Arief, Kejahatan Korporasi: The Hunt for Mega-Profits and The Attack on Democracy, Bayumedia Publishing, Malang, 2006.

Arief, Barda Nawawi, Bunga Rampai Kebijakan Hukum Pidana, Citra Aditya Bakti, Bandung, 2005.

- Beberapa Aspek Kebijakan Penegakan dan Pengembangan Hukum Pidana, PT. Citra Aditya, Bandung, 2005. 2003.

Budianto, Agus, Delik Suap Korporasi Di Indonesia, Cet. Pertama, Karya Putra Darwati, Bandung, 2012.

Hatrik, Hamzah, Asas Pertanggungjawaban Korporasi dalam Hukum Pidana Indonesia (Strick Liability dan Vicarious Liability), Raja Grafindo Persada, Jakarta, 1996.

Marzuki, Peter Mahmud, Penelitian Hukum edisi revisi, Kencana, Jakarta, 2005.

Muladi, Pertanggungjawaban korporasi Dalam Hukum Pidana, Sekolah Tinggi Hukum Bandung, Bandung, 1991.

- dan Barda Nawawi Arief, Teori-Teori Dan Kebijakan Pidana, Alumni, Bandung, 1998.

Muladi dan Dwidja Priyatno, Pertanggungjawaban Pidana Korporasi, Kencana Prenada Media Group, Jakarta, 2010.

Rachmad Budiono, Abdul, Hukum Perburuhan di Indonesia, Penerbit Raja Grafindo Persada, Jakarta, 1999. 
Reksodipuro dalam Sutan Remy Sjahdeini, Pertanggungjawaban Pidana Korporasi dalam Tindak Pidana Korporasi, FH UNDIP, Semarang, 1989.

Sendjun H, Manulang, Pokok-pokok Hukum Ketenagakerjaan di Indonesia, Penerbit Rineka Cipta, Jakarta, 1995.

Setiyono, Kejahatan Korporasi: Analisis Viktimologis dan Pertanggungjawaban Korporasi dalam Hukum Pidana Indonesia, Bayumedia Publishing, Malang, 2005.

Sidharta, B. Arief, Meuwissen Tentang Pengembanan Hukum, Ilmu Hukum, Teori Hukum, dan Filsafat Hukum, Cet. Pertama, PT. Refika Aditama, Bandung, 2007.

Sjahdeini, Sutan Remy, Pertanggungjawaban Pidana Korporasi, Grafiti Pers, Jakarta, 2007.

Sjawie, Hasbullah F, Direksi Perseroan Terbatas serta Pertanggungjawaban Pidana Korporasi, Citra Aditya Bakti, Bandung, 2013.

Soepomo, Iman, Pengantar Hukum Perburuhan, Jambatan, Jakarta, 1985.

Soetiksno, Hukum Perburuhan, (tanpa penerbit), Jakarta, 1977.

Sudarto, Kapita Selekta Hukum Pidana, Alumni, Bandung, 2006.

Perundang-undangan

Undang-Undang Dasar Republik Indonesia 1945.

Kitab Undang-Undang Hukum Pidana (KUHP).

Kitab Undang-Undang Hukum Perdata (KUHPdt).

Undang-Undang Nomor 13 Tahun 2003 Tentang Ketenagakerjaan.

Undang-Undang Nomor 31 Tahun 1999 j.o Nomor 20 Tahun 2001 tentang Pemberantasan Tindak Pidana Korupsi.

\section{Situs Internet}

UU No. 23 tahun 1997 tentang Pengelolaan Lingkungan Hidup.

Evan Elroy Situorang, Tesis Kebijakan Formulasi Pertanggungjawaban Pidana Korporasi Terhadap Korban Kejahatan Korporasi (online), http://eprints.undip.ac.id/16888/1/EVAN ELROY SITUORANG.pdf (15 November 2012).

http://become-teacher.blogspot.com/2013/05/pengertian-kebijakan.html. https://bamstero.wordpress.com/2013/06/16/jenis-tindakan-pidana-dalamketenagakerjaan.

http://e-journal.unair.ac.id/index.php/YDK/article/viewFile/3 
